\title{
Bank Customers Loyalty:A Case Study of Birhan International Bank (BIB), Ambo Branch, West Shoa Zone, Oromia Regional State, Ethiopia
}

\author{
Negash Geleta Etana \\ Ambo University, College of Business and Economics, \\ Department of Management, P.O. Box: 119, Ethiopia
}

\begin{abstract}
During the past decade, the financial service industry has undergone drastic change and intense competition in Ethiopia. In increasingly competitive markets, being able to build customer loyalty is seen as the key factor in winning market share and developing a sustainable competitive advantage. It should be imperative to apply the modern innovative marketing strategy to the banking industry in Ethiopia that focuses on keeping and improving current customers rather than acquiring new customers. The objective of this study was to identify factors that influence customer loyalty in banking industry of Ethiopia. In order to achieve the aim of this study the researcher applied both descriptive and explanatory research design. The researcher selected BIB based on special cases that was most of customers complain the bank and 332 questionnaires were distributed to respondents but only 274 retuned and used for analyze data. The data gathered from respondent analysis was done using the SPSS software program. The main finding of study shows that commitment, customer satisfaction and trust have positive and a significant influence in determining customer loyalty. Therefore, managements in banking industry specifically in BIB should focus on the determinants of customer loyalty.
\end{abstract}

Keywords: Customer loyalty, Perceived quality, Customer Satisfaction, Switching cost, Trust \&Commitment.

DOI: $10.7176 / \mathrm{EJBM} / 12-35-04$

Publication date: December $31^{\text {st }} 2020$

\subsection{Introduction}

Customer loyalty is a deeper confidence to the firm which leads to customer retention (K. D. Hoffman and J.E. G. Bateson, 2011). According to Beerli, Martin and Quintana (2004), the service industry, such as banks, has been accompanied by a bundle of works on customer loyalty. In addition Lin and Wang (2006), defined customer loyalty as the customer's favourable attitude towards a brand, resulting in repeat purchase behaviour. According to Lam, Shun, and Sanker (2004), customer loyalty has a powerful impact on firm's performance and is considered by many companies as an important source of competitive advantage. For any organization to be successful in the future, it is important to maintain a high rate of customer loyalty since costs of acquiring a new customer is high compared to maintaining existing customer (Akhter et al., 2011). One of the strategies adopted by worldwide organizations is to focus on creating long-term relationships with consumers, by building customer loyalty (Kumar, Batista \& Maull, 2011) which creates satisfied customers to purchase more products or services from provider and results profitability for organization by keeping the advertising and other marketing costs low and giving referrals to their friends by word of mouth. So it can be viewed as a strategy that creates mutual rewards both for firms and customers (Murugan, 2013). In addition customer loyalty has many advantages for a company such as reduction in marketing and customer support costs (Pratminingsih, Lipuringtyas \& Rimenta, 2013); it creates a suitable platform for new products and line extensions for the company (Berry, 2000). Several factors have been found to positively affect customer loyalty include customer satisfaction, perceived value, perceived trust, service quality, corporate image/brand image (Kumar, Batista \& Maull, 2011). Customers remain loyal to the company that serves their needs and preferences with a total set of related products and services, while on the other hand companies demonstrate and maintain their loyalty to the customers by becoming knowledgeable about them and responding to them with enhanced product offerings (Kahora, 2012).

\subsection{Statement of the Problem}

The Ethiopian economy which had exhibited 9.1 percent average annual growth during 2014/15-2018/19, registered 9 percent expansion in 2018/19, showing improvement relative to the 7.7 percent growth of last year although it was 2 percentage point lower than the base case scenario of GTP II target set for the year. The growth in real GDP was mainly attributed to 11 percent growth in services, 3.8 percent in agriculture and 12.6 percent in industrial sectors (World Economic Outlook Update, October 2018). According to National Bank of Ethiopia report new branches opened by existing bank which increase total branch network every year. This event creates an opportunity for customers to choose the bank they want. Then banks have to choose the strategy that help in retaining the existing customers and enhance their loyalty in the long run. Lauren and Lin (2003) suggest that to increase sales volume of services, firms should focus on customer loyalty towards their product and service. Thus, 
business decision makers and executives should search new innovative strategies to keep their existing customers loyalty towards their products and services, and also to further increase the base of loyal customers. Customer loyalty brings many benefits such as the positive word of mouth Dick and Basu (1994) and Oliver (1999), it increase the relative bargaining power of organization and also increase Return on Investment (Anderson, Formell and Mazvancheny ,2004). According to Rust and Zahorik (1993) identify that attracting new customers may be five times as costly as keeping existing customers. Loyal customers not only increase the value of the business, but also enable it to maintain the costs lower than those associated with attracting new customers Beerli et al. (2004). Top $20 \%$ of customers are likely to produce $80 \%$ profit for the company. Kotler and Keller (2005) due to the above benefits, each bank would like to exert extra effort to retain existing customers. During the past decade, the financial service industry has undergone drastic change and intense competition in Ethiopia. It will be imperative to apply the modern innovative marketing strategy called customer loyalty to the banking industry of Ethiopia. Some research conducted in Ethiopia showed positive relationship of customers' loyalty with bank performance. From these researches the research conducted by Efrem (2013) shows that commitment, satisfaction and trust have a significant positive influence on customer loyalty. The development of Loyalty involves building and sustaining a relationship with a customer, which leads to the repeated purchase of products or services over a given period of time (Magutu, 2009). The rise in the number of financial institutions that are designing new initiatives to pursue the under banked consumer market illustrates the recent realization of retail banking that there is such huge potential within that group. This requires that the Bank does more if it is to increase the level of their customers' satisfaction and improve their chances of continued transacting. This has led to the introduction of banking services through electronic channels (e-channels) namely ATMs, personal computer banking and phone banking which have provided an alternative means to acquire banking services more conveniently (Murugan, 2013). In spite of the above studies on customer loyalty, there has not been one that touches on Birhan banks to understand the factors influencing customer loyalty. Given the importance of customer loyalty, this study sought to determine factors influencing customer loyalty on Birhan banks in Ambo Branch. To bridge the above mentioned gaps, this study tried to identify factors that affect customer loyalty in the Banking industry of Ethiopia.

\subsection{Study Objectives}

1. To identify factors affecting customer loyalty in BIB.

2. To examine the effect of factors affecting customer loyalty in BIB.

\subsection{Significance of the Study}

This study primarily helps banking industry in Ethiopia especially BIB. It may help managements to better decision making on customer loyalty program, customer relationship management to improve the bank competitive position. Additionally this study help other practitioners or researchers use as reference by providing important input to shield light for further studies.

\subsection{Related Literature}

\subsection{Customer Loyalty}

The increasing importance of relational marketing in recent years, particularly in the service industries, such as banks, has been accompanied by a bundle of works on customer loyalty. Beerli et al. (2004) defined loyalty as repeat purchasing frequency or relative volume of same-brand purchasing. Similarly, Oliver (1999) defines loyalty as a deeply held commitment to re-buy or re-patronize a preferred product/service consistently in the future, thereby causing repetitive same-brand set purchasing, despite situational influences and marketing efforts having the potential to cause switching behavior. Their analysis concludes that consistent purchasing as an indicator of loyalty could be invalid because of happenstance buying or a preference for convenience and that inconsistent purchasing could mask loyalty if consumers were multi-brand loyal. So it is conclude that the simply repetitive purchasing is not the base brick of customer loyalty. Customer loyalty is a variable of having two dimensions, one is related to the behavior and other related to the attitude, where commitment in the essential features. According to Dick and Basu (1994), argued that loyalty is determined by the strength of the relationship between relative attitude and repeat patronage and that has both attitudinal and behavioral elements.

\subsection{Factors Affecting Customer Loyalty in Banking Sectors \\ 2.2.1. Perceived Quality}

In this study, perceived quality is defined as an overall judgment and the generally excellent or the superiority evaluated by customer on the services quality (Zeithaml et al., 1988). It is pointed out that balancing customer expectation in delivering services quality influenced customer satisfaction towards services providers (Zeithaml et al., 1996). However, (Ibid) stated that perceived services quality is the difference or comparison of customer expectation with their perceptions of performance. Recently, researchers have investigated a variety of approaches to measure perceived quality. It has also been found that when the perceived value was low, customers would be 
more inclined to switch to competing businesses in order to increase perceived value, thus contributing to a decline in loyalty (Malik, 2012). Further studies indicate that all the dimensions of service quality have a positive and significant influence on customer loyalty banking industry (Auka et el., 2013).

\subsubsection{Customer Satisfaction}

In the highly competitive business world of today, customer satisfaction can be seen as the substantial of success, which can lead to customer retention and profitability for organization Jemal and Kamal (2004). In 1980, Oliver defined customer satisfaction is "complete fulfilment of his/her expectations". It is an attitude or feeling that results from the use of a successful product or service. According to (Chavan et al., 2013), bank business depends very much on the quality of the customer service provided and overall satisfaction of customers. Customer satisfaction is a satisfied feeling toward the performance of product/service after they consume or use it (Belás, 2014). The former, (Chavan et al., 2013) have further defined eight of the most important attributes of satisfaction: paying individual attention to each client, personnel behavior inducing customer trust, attractive bank equipment, zero fees for issuing checks, zero error records, the possibility of online banking, security of transactions, helpful staff, and readiness of staff to answer to customer requirements regardless of occupancy. A satisfied customer is willing to use the same product despite of the change in price and time (Fraering et al., 2013).

\subsubsection{Switching Cost}

Consumers incur one-time costs when switching from one supplier or marketplace to another. These costs are called switching costs (Porter, 1980). Switching cost is a main reason why buyers stay with or switch a seller. Most researchers agree that switching costs reduce switching because they make customers more difficult or costly to change providers (Jones et al., 2000). Switching costs include not only economic costs but also search costs, transaction costs, learning costs, loyal customer discounts, customer habit, and emotional cost (Claes, 1992). Another researcher (Lee et al., 2011) identified three types of switching costs: procedural, financial and relational switching costs (Lee and Chung, 2011). Antecedents of switching costs include three components: market characteristics, consumer investments and domain expertise (Lee and Chung, 2011). In prior research, some scholars studied the antecedents of switching costs on the following components: customer supplier relationship characteristics and customer relationship (Barroso and Picón, 2012).

\subsubsection{Customer Trust}

Trust has been defined as the level of integrity, honesty and competence that one party perceives in another. In other words, it depends on the perceived reliability and integrity of a brand or service provider. Henning-Thurau et al, (2007) argue that the direct influence of trust on loyalty has been questioned by a number of empirical studies. In support, Ranaweera \& Prabhu, (2003) argued that trust in the context of one company to another has been used in a somewhat ambivalent way. Chiou, Droge \&Hanvanich(2002) argue that when a customer trusts a brand, it means that it is also likely to form a positive attitude towards the brand. Trust is logically and experientially a critical variable in relationships and this has long been assumed and confirmed in the marketing literature (Moorman et al., 1993; Morgan \& Hunt, 1994). Those who do not want to trust a supplier in a competitive market are unlikely to find loyalty. The importance of trust in the explanation of loyalty is also supported by the authors (e.g, Lim et al. 1997; Chaudhuri \& Holbrook 2001).Trust in performance or credibility is an important aspect of the relationship between banks and consumers.

\subsubsection{Commitment}

According to (Morgan et al.., 1994), commitment stems from trust, shared values and the belief that it will be difficult to find partners that can offer the same value. Commitment encourages partners to collaborate in order to preserve investments in the relationship (Ibid). Rauyruen et al., (2007) further define commitment as "a psychological sentiment of the mind through which an attitude concerning continuation of a relationship with a business partner is formed". The reasoning is that without high commitment of the customers, it will not bring about customer loyalty. Besides, customer commitment mediates the influence of customer satisfaction and customer loyalty (Zafar, 2012). From above literatures, it can be predicted that if customers are committed to use bank services, they are likely to make the repeat purchase.

\subsubsection{Bank Image}

According to $\mathrm{Wu}$ (2011), a brand is a distinguishing name and/or symbol such as logo, trademark, or package design intended to identify the goods or services of either one seller or a group of sellers, and to differentiate those goods or services from those of competitors. A brand name is an intangible signifier of the physical entity, acting as a surrogate for the individual characteristics of products or services, related more to the company's reputation than to the lines it sells. In traditional brand measuring the familiarity, attitudes and knowledge are priorities (Solja, 2012). Saleem and Naintara (2014) claim that high customer satisfaction develops positive corporate image because they will provide positive word of mouth. As per Balderston, F (1985) stated brand is a mental image that reflects the way a brand is seen, including all the recognizing components, the product or organization identity, and the feelings and association evoked in the buyer's brain. Also Keller (1993) characterizes brand as recognitions about a brand as reflected by the brand association held in the purchaser's memory. Davies et al. (1995) proposed that branding relates closely to customer loyalty. Since brand image has been recognized as an important factor to 
customer loyalty, banks with a positive brand image will tend to generate higher levels of customer loyalty.

\subsubsection{Corporate Culture}

Organizational culture refers to a system of shared meaning held by members that distinguishes the organization from other organizations. The corporate culture is probably the element, which is least mentioned in the literature. Often it does not even appear in the marketing literature on identity and image. Nonetheless, several researchers have tried to define the term and one of them is Sirapracha and Tocquer (2013) "The concept of corporate culture broadly concerns all aspects of everyday organizational life, in which meaning, values, and assumptions are expressed and communicated via the behaviour and interpretations of organizational members and their artefacts and symbols" (Ibid Saleem and Naintara (2014) shares the same opinion, as according to her corporate culture is built around the same logo, which is repeated perpetually on study, folders and publications, around the same basic values, which are repeated perpetually in speeches, annual reports and press releases and around the same stories, which are told perpetually to new employees, laughed about Friday afternoon and discussed in elevators (Wu, 2011).

\section{Methodology}

\subsection{Study Area}

The study was conducted in Oromia Regional State, West Shoa Zone, Ambo Town, which is far $119 \mathrm{~km}$ from Addis Ababa, Capital City, Ethiopia, in the case of BIB Ambo Branch.

\subsection{Research Design}

This study used a quantitative approach which includes both descriptive and casual designs. Descriptive design was used to obtaining information on current state of phenomena and an explanatory design preferred since it explains a situation in the form of casual relationships.

\subsection{Data and Collection Instrument}

The study used primary sources of data. This data was collected through survey method using a questionnaire from bank customers. This data was collected during June 2020.

\subsection{Population, Sample Size and Sampling Techniques}

The target populations for this study were customers of bank those are active account holder which account about 2057. For sample size determination Krejcie and Morgan (1970) method was employed. According to this method a sample of 323 represent 2,000 populations. Based on this, customers were selected proportionally. Accordingly the totals of 332 copies of questionnaire were distributed to customers. From these only 274 were returned, which represents about $82.5 \%$ of the total population. Since convenience sampling is very advantageous to quickly get respondents and also economical it was chosen as sampling method.

\subsection{Validity and Reliability}

To increase validity the research has done pilot taste of questionnaire to fifteen customers of the bank to see whether the questionnaire were clear and understandable or not. And questionnaire has given to respondent faceto-face. If they face any difficulty while filling out the questionnaire the ambiguity were explained. So the researcher made modification on questionnaire. To check the reliability of the data Chronbach's alpha was found to be $>0.70$, then it has taken as reliable.

\subsection{Variables and Model Specification}

For this study both dependent and independent variables were identified. Accordingly the dependent variable of the study was bank customer loyalty and independent variables (perceived quality, customer satisfaction, switching cost, customer trust, commitment, bank image and corporate culture). The model selected for this study was multiple linear regressions (MLR) AS follows;

$$
\begin{aligned}
& \mathbf{Y}=\mathbf{\partial}+\boldsymbol{\beta} 1 \times 1+\beta 2 \times 2+\beta 3 \times 3+\beta 4 \times 4+\beta 5 \times 5+\beta 6 \times 6+\beta 7 \times 7+£ \\
& \text { CBL }=\mathbf{\partial}+\beta 101+\beta 2 S 2+\beta 3 S C 3+\beta 4 \times T 4+\beta 5 C 5+\beta 6 B I 6+\beta 7 C C 7+£ \\
\text { Where, } & \\
> & C B L=\text { Customer Bank Loyalty } \\
> & \partial=\text { constant } \\
> & £=\text { error } \\
> & X 1-x 7 \text { independent variables }
\end{aligned}
$$

\subsection{Data Analysis}

The collected data via questionnaires was analyzed using descriptive (mean and standard deviation) and inferential statistics (t-test, correlation and regression). To analyze the collected data SPSS V.23 was employed. 


\section{Results and Discussion}

\subsection{Respondents Profiles}

Table 4.1.Respondents Profiles

\begin{tabular}{|l|c|c|c|c|}
\hline \multicolumn{2}{|c|}{} & Frequency & Percent & Valid Percent \\
\hline \multirow{4}{*}{ Gender } & Male & 177 & 64.6 & 64.6 \\
\cline { 2 - 5 } & Female & 97 & 35.4 & 35.4 \\
\cline { 2 - 5 } & Total & 274 & 100.0 & 100.0 \\
\cline { 2 - 5 } & $15-25$ & 95 & 34.7 & 34.7 \\
\cline { 2 - 5 } & $26-35$ & 123 & 44.9 & 44.9 \\
\cline { 2 - 5 } & above 36 & 56 & 20.4 & 20.4 \\
\hline \multirow{5}{*}{ Education } & Total & 274 & 100.0 & 100.0 \\
\cline { 2 - 5 } & Below grade 12 & 88 & 32.1 & 32.1 \\
\cline { 2 - 5 } & Diploma/Levels & 63 & 23.0 & 23.0 \\
\cline { 2 - 5 } & BA degree & 65 & 23.7 & 23.7 \\
\cline { 2 - 5 } & Master \& above & 58 & 21.2 & 100.0 \\
\cline { 2 - 5 } & Total & 274 & 100.0 & 23.0 \\
\hline Occupation & Government & 63 & 23.0 & 40.5 \\
\cline { 2 - 5 } & private & 111 & 40.5 & 26.3 \\
\cline { 2 - 5 } & NGO & 72 & 26.3 & 10.2 \\
\cline { 2 - 5 } & no job & 28 & 10.2 & 100.0 \\
\cline { 2 - 5 } & Total & 274 & 100.0 & \\
\hline
\end{tabular}

Source: Survey Data 2020

As shown in table 4.1 above, more of the respondents $64.6 \%$ were male and on the other hand, about $35.4 \%$ were female. The survey revealed that the age of respondents were in all age groups of customers. The majority of the respondents $44.9 \%$ were fall in the age range of 26 to 35 while $34.7 \%$ were 15 to 25 and $20.4 \%$ were above age which held the smallest age group of bank customers. In terms of educational attainment, about $32.1 \%$ were below grade 12 while $23.0 \%$ diploma holder, $23.7 \%$ BA degree, and $21.2 \%$ masters and above. This indicate that majority of customers of the bank have good access to information about the bank facilities. About occupation of respondents, $40.5 \%$ of respondents were from private and $26.3 \%$ were from NGO $23.0 \%$ from government and $10.2 \%$ of respondent were no jobs. Therefore, most of the customers of available in the survey were private sector and NGO sector.

\subsection{Reliability Test}

Table 4.2. Reliability Test

\begin{tabular}{|l|r|}
\hline \multicolumn{2}{|c|}{ Reliability Statistics } \\
\hline Cronbach's Alpha & N of Items \\
\hline
\end{tabular}

Source: Survey Data 2020

To be certain of the validity as well as the reliability of the information, this analysis initially pre-tested the questionnaire by reviewing professionals and discussed on it. Concerning reliability, all of the things show a strong inner consistency measuring the constructions of it by reaching Cronbach's alpha greater than 0.70 . The outcome has satisfied the minimum acceptable Cronbach's alpha coefficient of 0.70 as indicated by Hair et al. (1998). Thus, they recommended that the requirements properly assessed for variables. Thus, Cronbach's Alpha is clearly positively significant. The measurement of the reliability of the variables is actually provided in table 4.2

\subsection{Results of Descriptive Analysis T -Test}

Table 4.3.T-Test of Variables

\begin{tabular}{|ll|c|c|c|c|}
\hline & Mean & Std. Deviation & $\mathrm{t}$ & Sig. (2-tailed) \\
\hline 1) & Perceived Quality & 3.0620 & .40737 & 124.421 & .000 \\
\hline 2) & Customer Satisfaction & 3.0748 & .36658 & 138.845 & .000 \\
\hline 3$)$ & Switching Cost & 3.0961 & .25376 & 201.957 & .000 \\
\hline 4$)$ & Commitment & 2.8591 & .36133 & 130.981 & .000 \\
\hline 5) & Brand Image & 2.8775 & .38584 & 123.447 & .000 \\
\hline 6$)$ & Organizational/ Bank Culture & 3.0304 & .31976 & 156.875 & .000 \\
\hline 7$)$ & Trust & 2.7476 & .42058 & 108.137 & .000 \\
\hline
\end{tabular}

Source: Survey Data 2020

In table 4.3 the result of 7 variables were summarized based on the mean, SD and t-test. Accordingly the first was perceived quality. As the result revealed, the mean obtained was 3.0620. This implies majority of the 
respondents neutral that perceived quality variable was not playing an important role in influencing their loyalty. By the same manner the left variables were presented in the above table. The t-test values of the all variables are statistically significant at $5 \%$ level. Accordingly the t-values for all variables were greater than the table value (1.96). Based on this, it can be concluded that all variables are influencing consumers' loyalty to the selected bank

\subsection{Results of Inferential Analysis}

4.4.1. Correlations Results

Table 4.4: Correlations Results

\begin{tabular}{|c|c|c|}
\hline & & Customer Loyalty \\
\hline \multirow[t]{2}{*}{ 1) Perceived Quality } & Pearson Correlation & $.569^{* * *}$ \\
\hline & Sig. (2-tailed) & .000 \\
\hline \multirow[t]{2}{*}{ 2) Customer Satisfaction } & Pearson Correlation & $.660^{* * *}$ \\
\hline & Sig. (2-tailed) & .000 \\
\hline \multirow[t]{2}{*}{ 3) Switching Cost } & Pearson Correlation & $.128^{*}$ \\
\hline & Sig. (2-tailed) & .034 \\
\hline \multirow[t]{2}{*}{ 4) Commitment } & Pearson Correlation & $.369^{* * *}$ \\
\hline & Sig. (2-tailed) & .000 \\
\hline \multirow[t]{2}{*}{ 5) Brand Image } & Pearson Correlation & $.480^{* * *}$ \\
\hline & Sig. (2-tailed) & .000 \\
\hline \multirow[t]{2}{*}{ 6) Organizational/ Bank Culture } & Pearson Correlation & $.600^{* * *}$ \\
\hline & Sig. (2-tailed) & .000 \\
\hline \multirow[t]{2}{*}{ 7) Trust } & Pearson Correlation & $.333^{* * *}$ \\
\hline & Sig. (2-tailed) & .000 \\
\hline
\end{tabular}

Source: Survey Data 2020

Correlation examination is utilized for describing the power as well the guidance of the linear connection between two variables. Pearson correlation coefficients (r) are only able to take values from -1 to +1 . When the value of $\mathrm{r}$ is between 0.1 to 0.29 the relationship is vulnerable/weak; when the value of $\mathrm{r}$ is between 0.30 and 0.49 , the relationship average, and when the value of $\mathrm{r}$ is above 0.50 , the relationship is strong (Pallant, 2001). The correlation analysis involves the dependent adjustable variable of customer loyalty and the factors. The result of the analysis is shown in table. Table 4.4 indicate all variables were positively correlated with customer loyalty. As seen from the table perceived quality, customer satisfaction and organizational/ bank culture had correlation values of greater than 0.5 . For those variables there is a strong positive relationship between customer loyalty and for commitment, brand image and trust their relationship was average since their value was between 0.30 and 0.49 . Lastly, there was a strong positive and weak relationship between switching cost and customer loyalty.

\subsubsection{Multi-Collinearity Results}

Table 4.4 test

\begin{tabular}{|c|c|c|c|}
\hline \multicolumn{4}{|c|}{ Coefficients $^{a}$} \\
\hline \multirow{2}{*}{\multicolumn{2}{|c|}{ Model }} & \multicolumn{2}{|c|}{ Collinearity Statistics } \\
\hline & & Tolerance & VIF \\
\hline \multirow[t]{7}{*}{1} & 1) Perceived Quality & .564 & 1.774 \\
\hline & 2) Customer Satisfaction & .775 & 1.290 \\
\hline & 3) Switching Cost & .986 & 1.014 \\
\hline & 4) Commitment & .607 & 1.646 \\
\hline & 5) Brand Image & .685 & 1.460 \\
\hline & 6) Bank Culture & .623 & 1.606 \\
\hline & 7) Trust & .829 & 1.206 \\
\hline \multicolumn{4}{|c|}{ a. Dependent Variable: Customer Loyalty } \\
\hline
\end{tabular}

Source: Survey Data 2020

Multi-collinearity refers to the situation in which the independent variables are highly correlated. When independent variables are multi-collinearity, there is "overlap" or sharing of predictive power (Dillon, 1993). This may lead to the paradoxical effect, whereby the regression model fits the data well, but none of the predictor variables has a significant impact in predicting the dependent variable (Robert, 2006). The multi-collinearity in this study was checked using the Tolerance and VIF value. As it is showed in the table all independent variables have a Tolerance value greater than 0.01 and VIF value less than 10. The VIF, Variance inflation factor, is computed as "1/Tolerance", and it is suggested that predictor variables whose VIF values are greater than 10 may merit further investigation (Robert, 2006). 


\subsubsection{Results of Model Summary}

Table 4.5 Model Summary

\begin{tabular}{|c|c|c|c|c|}
\hline \multicolumn{5}{|c|}{ Model Summary } \\
\hline Model & $\mathrm{R}$ & R Square & $\begin{array}{c}\text { Adjusted R } \\
\text { Square }\end{array}$ & $\begin{array}{c}\text { Std. Error of the } \\
\text { Estimate }\end{array}$ \\
\hline 1 & $.839^{\mathrm{a}}$ & .704 & .696 & .18878 \\
\hline \multicolumn{5}{|r|}{ a. Predictors: (Constant), T, SC, C, S, BI, BC, Q } \\
\hline
\end{tabular}

Source: Survey Data 2020

The above table shows model summary(R). Larger values of $\mathrm{R}$ indicate stronger relationships. In this model, the value is $.839^{\text {a }}$, which indicates that dependent variable has strong relationship with the independent variables. $R$ square is simply the squared value of $R$. This is frequently used to describe the goodness-of-fit or the amount of variance explained by a given set of predictor variables. The value 704 indicates that variation in customer loyalty can be explained by the independent variables in the model. In other word $29.6 \%$ of the change in dependent variable-customer loyalty not explained, which means other factors which contributes for this change.

\subsubsection{Results of ANOVA}

Table 4.6 ANOVA result

\begin{tabular}{|l|l|c|c|c|c|c|}
\hline \multicolumn{7}{|l|}{ ANOVA $^{\text {a }}$} \\
\hline \multirow{2}{*}{\begin{tabular}{l} 
Model \\
\hline
\end{tabular}} & Sum of Squares & df & Mean Square & F & Sig. \\
\cline { 2 - 7 } & Residual & 9.480 & 7 & 3.213 & 90.168 & $.000^{\text {b }}$ \\
\cline { 2 - 7 } & Total & 31.974 & 273 & .036 & & \\
\hline \\
\hline
\end{tabular}

Source: Survey Data 2020

The ANOVA table describes the overall variance accounted for the model. If the significance value of the $F$ statistic is small (smaller than 0.05) then the independent variables do a good job explaining the variation in the dependent variable. If the significance value of $\mathrm{F}$ is larger than say 0.05 then the independent variables do not explain the variation in the dependent variable. The above ANOVA table has confirmed the explained variance by the model could truly explain the change in customer loyalty ( $\mathrm{F}$ ratio $=90.168, \mathrm{P}<0.05$ ). Then in the above table, independent variables are a good determinant of bank customer loyalty.

\subsubsection{Results of Regression}

The regression analysis fit a model to data and uses it to forecast the value of the dependent variable from the one or more independent variables. This research uses multiple linear regression analysis (more than one predictor) to determine the value of the dependent variable

Table 4.7 Regression Results

\begin{tabular}{|c|c|c|c|c|c|c|}
\hline \multicolumn{7}{|c|}{ Coefficients $^{\mathbf{a}}$} \\
\hline \multirow{2}{*}{\multicolumn{2}{|c|}{ Model }} & \multicolumn{2}{|c|}{ Unstandardized Coefficients } & \multirow{2}{*}{$\begin{array}{c}\begin{array}{c}\text { Standardized } \\
\text { Coefficients }\end{array} \\
\text { Beta } \\
\end{array}$} & \multirow[b]{2}{*}{$\mathrm{t}$} & \multirow[b]{2}{*}{ Sig. } \\
\hline & & $\mathrm{B}$ & Std. Error & & & \\
\hline \multirow[t]{8}{*}{1} & (Constant) & -.658 & .196 & & -3.356 & .001 \\
\hline & Perceived Quality & .274 & .037 & .326 & 7.331 & .000 \\
\hline & Customer Satisfaction & .441 & .035 & .472 & 12.447 & .000 \\
\hline & \begin{tabular}{|l|} 
Switching Cost \\
\end{tabular} & .135 & .045 & .100 & 2.977 & .003 \\
\hline & Commitment & .017 & .041 & .017 & .408 & .684 \\
\hline & Brand Image & .100 & .036 & .113 & 2.799 & .005 \\
\hline & Bank Culture & .182 & .045 & .170 & 4.021 & .000 \\
\hline & Trust & .076 & .030 & .094 & 2.554 & .011 \\
\hline
\end{tabular}

\section{Source: Survey Data 2020}

Regression Results, $\mathrm{CL}=-.658+.274 Q+.441 S+.135 S C+.017 C+.100 B I+.182 B C+.076 T+£$

The results indicate that the variables are the predictors of customer loyalty in BIB. Meanwhile, for the first variable a beta value of .274 indicates that 1 unit increase in the bank perceived quality will result in a .274 unit increase in the customer loyalty variable. For the other variables the same fashion can be considered. The empirical findings of this study are consistent with the evidences offered by Carroll\& Shabana, (2010); Elizabeth Brown, (2012); Parasuraman et al., (1991) and Rahi, S (2015). The major findings of this study have indicated that bank image, bank services quality, customer satisfaction and customer trust play an important role in building customer loyalty in banks industry. Additionally, all independent variables are highly significant, positive influence on customer loyalty to ensure customer loyalty in selected bank except commitment. 


\section{Conclusion and Recommendation}

The purpose of this paper was to examine the determinants of customer loyalty in banking industry specifically in BIB. This investigation concluded that the variables chosen to analyze the determinants of customer loyalty can be considered reliable and consistent. Then accordingly it can be concluded that all variables are the most determinants of customer loyalty in banking industry except commitment. The implication of these findings is that measures should be taken by managers of the bank to improve customers' loyalty in banking industry. So it is imperative for the banks to maintain a clear and transparent relationship with their clients in order to be satisfied and thus loyal.

\section{Study Limitations and Areas for Further Research}

This study reviewed the past researches to investigate the factors affecting customers' loyalty in banking industry. That being the case, it was difficult to establish the reliability and validity of the data. Furthermore, the reviewed studies came from different countries which could have the different geographical environment, culture and consumer behavior. Further research can be done in Ethiopia by using the primary data so as to get the findings and recommendations that fit the Ethiopian banking industry context.

\section{Reference}

$>$ Akhter, M. F., Ali, K., \& Sadaqat, S. (2011). Liquidity Risk Management: A comparative study between Conventional and Islamic Banks of Pakistan. "Interdisciplinary Journal of Research in Business", 1(1), 35-44.

$>$ Anderson, Fomell and Mazvanchen(2004). Customer Satisfaction and Shareholder value. Journal of Marketing, 68, 172-185.

$>$ Auka, D. O., Bosire, J. N., \& Matern, V. (2013). Perceived service quality and customer loyalty in retail banking in Kenya. British Journal of Marketing Studies, 1, 32-61.

$>$ Balderston, F. (1985). Book Review: Competitive AdvantageCompetitive Advantage by PorterMichael (New York, NY: The Free Press, 1985). California Management Review, 28(1), 179-184.

$>$ Barroso, C and Picón, A. (2012). Multi-dimensional analysis of perceived switching costs. Industrial Management , 41.

$>$ Beerli,A, Marti, J.D. and Quintana, A. (2004). A model of customer loyalty in the retail banking Market, European Journal of Marketing, 38, 253-275.

$>$ Beerli,A, Marti, J.D. and Quintana, A. (2004). A model of customer loyalty in the retail banking Market, European Journal of Marketing,38, 253-275.

$>$ Belás, J. G. (2014). Reasons for satisfaction and dissatisfaction of bank customers. Study from Slovakia and the Czech republic. International Journal of Entrepreneurial Knowledge , 2 (14), 4-13.

$>$ Berry L. L. (2000). Cultivating Service Brand Equity, Journal of the Academy of Marketing science, 28(1), pp. 128-137.

$>$ Chaudhuri A, Holbrook MB (2002). "The Chain of Effects from Brand Trust and Brand Affect to Brand Performance: The Role of Brand Loyalty April." J. Mark. 65(2): 81-93.

$>$ Chavan, J., Ahmad, F. (2013). Factors Affecting On Customer Satisfaction in Retail Banking: An Empirical Study. International Journal of Business and Management Invention, 2 (1), 55-62.

$>$ Chiou, Y. and Droge, W. (2009)."Customer value toward short message service: an empirical investigation", The International Journal of Organizational Innovation, Vol. No.1, page (356- 368).

$>$ Claes, F. (1992). A National Customer Satisfaction Barometer: The Swedish Experience. Journal of Marketing , 1 (56).

$>$ Davies, F., Moutinho, L., \& Curry, B. (1995). Construction and testing of a Knowledge-based system in retail bank marketing. International Journal of Bank Marketing, 13 (2), 235-260.

$>$ Dick, A.S. and Basu K.(1994). Customer Loyalty: Toward an Integrated Conceptual Framework. Journal of Academics Marketing, 22, 99-113.

$>$ Efrem Hailu, (2013).Factors affecting customer loyalty in Banks: The case of Cooperative Bank of Oromia. Unpublished Master"es Thesis, Addis Ababa University School of Commerce.

$>$ Fraering, M., Minor, M. S. (2013). Beyond Loyalty: Customer Satisfaction, Loyalty and Fortitude. Journal of Service Marketing , 27 (4), 334-344.

> Hennig-Thurau, Thorsten, Andre' Marchand, and Paul Marx (2007), "When Consumers are Agents: Can Recommender Systems Help Make Better Choices,' ' working paper, Bauhaus-University of Weimar.

$>$ Hoffman, k., Douglas Bateson. John.eg, 2011. Surface marketing, concepts strategies \& cases, south - western, engaged learning U.S.A

$>$ Jemal, A. Kamal, N. (2004). Customer satisfaction and retail banking: an assessment of some of the key antecedents of customer satisfaction in retail banking. International Journal of Bank Marketing, 20,146-160.

$>$ Jones, M.A; Mothersbaugh \& A. Burnham, T.A. (2000). Switching Barriers and Repurchase Intentions in Services". Journal of Retailing , 2 (76). 
$>$ Kahora, B. (2012). Cell phone Revolution in Kenya.International Policy Network.

$>$ Keller, K. (1993). Conceptualizing, Measuring, and Managing Customer-Based Brand Equity. Journal of Marketing, 57(1), 1.

$>\quad$ Kotler, P.and Keller, K.L.(2005).Marketing Management. Singapore: Pearson Education Asia Pvt. Ltd.

$>$ Kumar, Batista, and Maull(201) The Impact of Operations Performance on Customer Loyalty Service Science 3(2), pp. 158-171, C 2011 SSG

$>$ Lam, Shun Yin, Venkatash Shanker, and Bvsan Murthy (2004). Customer value, satisfaction, loyalty and switching costs: An illustration from a business to business service contexts. Journal of the Academy of marketing science, 32(3), 293-311.

$>$ Lauren, P. and Lin, H.H (2003). A Customer loyalty model for E-service context. Journal of Electronic Commerce Research. Vol. 4.

$>$ Lee, K.C, Chung, N and , Lee, S. (2011). "Exploring the influence of personal schema on trust transfer and swiching costs in brick-and-click bookstores. Information \& Management, 48.

$>$ Lim, A.and Quester, P. Lin (2003). Product involvement/brand loyalty: is there a link? Journal of product \& brand management, 12, 22-38. http://dx.doi.org/10.1108/10610420310463117

$>$ Lin, H.H. and Wang, Y.(2006). An examination of the determinants of customer loyalty in mobile commerce contexts, Information \& Management,43, 271-282.

$>$ Magutu, P. (2009), "The strategic benefits and challenges in the use of customer relationship management system among commercial banks in Kenya”, European Scientific Journal, Vol. 9, pp. 327-349.

$>$ Moorman, C., Deshpande, R. and Zaltman, G. (1993), "Factors Affecting Trust in Market Research

$>$ Relationships", Journal of Marketing, Vol. 57 No. 1, pp. 81-102.

$>$ Moorman, C., Zaltman, G. and Deshpande, R. (1992), "Relationships between Providers and Users of Market Research: The Dynamics of Trust within and Between Organizations", Journal of Marketing Research, Vol. 29 No. 3, pp. 314-329.

> Morgan, R. M. and Hunt, S. D. (1994), "The Commitment-Trust Theory of Relationship Marketing", Journal of Marketing, Vol. 58 No. 3, pp. 20-38.

$>$ Murugan, R. (2013). Customer loyalty intentions in broadband internet services, International Journal of Business Innovation and Research, 7 (4), 487-503

> Oliver, R. L. (1999). Whence consumer loyalty? Journal of Marketing, 63(2), 33-44.

$>$ Parasuraman, A., Zeithaml, V. A. and Berry, L. L. (1988). SERVQUAL: a multiple item scale for measuring consumer perceptions of service quality. Journal of retailing, Vol. 64, 12-40.

$>$ Parasuraman, A., Zeithaml, V. A. and Berry, L. L. (1996). SERVQUAL: a multiple item scale for measuring consumer perceptions of service quality. Journal of retailing, Vol. 64, 12-40.

$>$ Porter, M. E. (1980). Competitive Strategy: Techniques for analyzing industries and competitors "New Free Press".

$>$ Pratminingsih, S. A., Lipuringtyas, C. \& Rimenta, T. (2013). Factors Influencing Customer Loyalty toward Online Shopping, International Journal of Trade, Economics and Finance, 4 (3), 104-110

$>$ Ranaweera, C., \& Neely, A. (2003). Some moderating effects on the service quality-customer retention link. International journal of operations \& Production management, 23(2), 230-248.

$>$ Rauyruen, P., \& Miller, K.E. (2007). Relationship quality as a predictor of B2B customer loyalty. Journal of Business Research, 60, 21.31

$>$ Rust, R. T.and Zahorik, A. J. (1993). Return on Quality (RoQ): Making service quality financially accountable. Journal of Marketing, Vol. 59, 58-70.

$>$ Saleem, H. \& Naintara, S. R. (2014). The Impact of Service Quality on Customer Satisfaction, Customer Loyalty and Brand Image: Evidence from Hotel Industry of Pakistan, Middle-East Journal of Scientific Research 19 (5): 706-711.

$>$ Wu, C. (2011). The impact of hospital brand image on service quality, patient satisfaction and loyalty, African Journal of Business Management Vol. 5(12), pp. 4873-4882 Solja, S. (2012). A study of brand image; Case: Nightclub Bra, Jyväskylä. Unpublished Thesis, School of Business and Services Management, JAMK University of applied Sciences

$>$ Zafar, M. (2012). Zafar, M., (2012). Service Quality, Customer Satisfaction and Loyalty: An Empirical Analysis of Banking Sector. Zafar, M., (2012). Information Management and Business Review, 4 (3), 159 167. 